\title{
Persepsi Pasien tentang Kualitas Layanan Mempengaruhi Kepuasan Pasien Rawat Inap Kelas III Rumah Sakit
}

\author{
Sulistyaningsih ${ }^{*}$ Fitnaningsih Endang Cahyani, Nuli Nuryanti Zulala, Sri Lestari \\ Fakultas Ilmu Kesehatan Universitas 'Aisyiyah Yogyakarta \\ *corresponding author, e-mail: sulistyaningsih@unisayogya.ac.id
}

Received: 21/10/2019; Published: 17/03/2020

\begin{abstract}
Background: The higher quality of hospital services will cause customers to have a high level of satisfaction and behavior. The purpose of the study was to analyze the quality of hospital inpatient services. Method: The survey research method used cross-sectional design. The sample of this study was 172 third class inpatients in PKU Muhammadiyah Gamping Hospital determined by consecutive sampling. Results: The results of study showed that patients' perceptions about the quality of inpatient services were mostly good on all dimensions (58\%), most patients feel satisfied (63\%). Conclusion: Education is significantly related to patients' perceptions of the quality of the hospital inpatient services. The experience of patients being treated in hospital is significantly related to inpatient satisfaction. Patients' perceptions of the quality of hospital inpatient services are significantly related to patient satisfaction. The quality dimension that needs to be improved is empathy, while the best is reliability.
\end{abstract}

Keywords: quality; satisfaction; servequal; inpatient services

Copyright $\odot 2013$ Universitas Ahmad Dahlan. All rights reserved.

\section{Pendahuluan}

Kualitas layanan telah menjadi topik penelitian yang penting di berbagai industri, termasuk rumah sakit karena hubungan yang signifikan dengan biaya, keuntungan, kepuasan pelanggan, retensi pelanggan, dan jaminan layanan.(1) Kualitas pelayanan rumah sakit yang lebih tinggi akan menyebabkan pelanggan memiliki tingkat kepuasan dan perilaku yang tinggi.(2) Kualitas layanan yang dirasakan memiliki efek paling kuat pada kepatuhan perilaku melalui kepuasan pasien.(3) Evaluasi kualitas pelayanan rumah sakit telah dilakukan di banyak negara dengan hasil yang bervariasi. Kualitas pelayanan rumah sakit yang memuaskan pasien adalah di USA,(4,5) Swedia,(6) China, $(7,8)$ Thailand.(9) Kualitas pelayanan rumah sakit yang kurang memuaskan pasien untuk semua dimensi pelayanan adalah di Iran. $(10,11)$

Penilaian kualitas perawatan untuk anak-anak di 18 rumah sakit di Indonesia telah dilakukan di Provinsi Jambi, Jawa Timur, Kalimantan Tengah, Sulawesi Tenggara, Nusa Tenggara Timur, Maluku Utara). Hasil penilaian adalah tidak memadainya penggunaan pedoman pengobatan standar dan pemberian antibiotik irasional. Penilaian tentang pemantauan kemajuan dan perawatan pendukung juga buruk. Manajemen kasus untuk penyakit anak perawatan neonatal dan pemantauan pasien perlu diperbaiki.(12)

Pemerintah Indonesia telah berusaha memperbaiki kualitas pelayanan rumah sakit melalui peraturan pelaksanaan UHC di Indonesia. Rumah Sakit diwajibkan melakukan akreditasi untuk meningkatkan kualitas layanannya.(13) Rumah sakit diwajibkan untuk melakukan akreditasi minimal enam bulan setelah keputusan perpanjangan lisensi habis dan satu tahun setelah keputusan lisensi operasinya.(14) Lebih dari separuh dari seluruh rumah sakit di Indonesia belum diakreditasi oleh standar nasional dan belum memenuhi standar 
akreditasi internasional dari Joint Commission International ( $\mathrm{JCl}$ ). Kualitas pelayanan rumah sakit umum di Indonesia belum setara dengan rumah sakit internasional(15).

Aspek yang mempengaruhi kualitas layanan rumah sakit adalah daya tanggap, jaminan, keamanan, bukti nyata, komunikasi kesehatan dan orientasi pasien.(16) Keandalan dan daya tanggap (empati, bukti nyata, keandalan dan jaminan) mempengaruhi kepuasan pasien.(17) Kepuasan pasien berhubungan langsung dengan loyalitas pasien terhadap rumah sakit.(18)

Hasil evaluasi kepuasan pasien rawat inap di bangsal rawat inap kelas III RS PKU Muhammadiyah Gamping menunjukkan tingkat kualitas cukup.(19) Sebanyak 30\% pasien ibu nifas menyatakan tidak puas terhadap pelayanan asuhan kebidanan pada ibu nifas.(20) Berdasarkan latar belakang masalah tersebut, maka tujuan penelitian ini adalah menganalisis kualitas layanan rawat inap di Rumah Sakit PKU Muhammadiyah Gamping.

\section{Metode Penelitian}

Rancangan penelitian ini adalah penelitian kuantitatif yang dilakukan dengan metode survei pendekatan waktu cross-sectional.(21) Responden penelitian ini adalah pasien rawat inap kelas III Rumah Sakit PKU Muhammadiyah Gamping bulan Juni s.d. Juli 2019. Teknik penentuan sampel dilakukan dengan teknik consecutive sampling.(22) Jumlah sampel pasien adalah 172 orang, jumlah kuesioner yang diberikan adalah 200 orang. Kriteria inklusi sampel adalah minimal telah dirawat inap 1 hari dan bersedia menandatangani informed consent. Kriteria ekskluasi sampel adalah pasien bukan karyawan atau keluarga karyawan RS PKU Muhammadiyah Gamping.

Alat pengumpulan data penelitian ini adalah kuesioner SERVQUAL yang merupakan kuesioner tertutup untuk mengukur persepsi kualitas pelayanan dan kepuasan pasien. Kelebihan kuesioner SERVQUAL adalah dapat diterima sebagai standar untuk mengakses dimensi kualitas pelayanan yang berbeda; terbukti berlaku untuk sejumlah situasi layanan; telah dikenal dapat diandalkan; dapat digunakan dengan berbagai cara, untuk membandingkan kinerja di berbagai bagian layanan atau berbeda kelompok pelanggan; perusahaan dapat mengingatkan manajemen untuk mempertimbangkan persepsi manajemen dan pelanggan.(23) Kuesioner diadaptasi dari kuesioner Utami et.al. (24) Metode pengumpulan data penelitian adalah pengisian kuesioner oleh pasien rawat inap kelas III. Analisis Chi-Square dengan tingkat kepercayaan 95\% dilakukan untuk menganalisis hubungan dua variabel, yaitu hubungan variabel pendidikan, penggunaan jaminan kesehatan, kualitas layanan dengan kepuasan pasien rawat inap rumah sakit.

Penelitian ini dilaksanakan setelah mendapat persetujuan dari Komite Etik Penelitian Universitas 'Aisyiyah Yogyakarta No. 969/KEP-UNISA/IV/2019 tanggal 9 April2019 dan surat ijin penelitian dari RS PKU Muhammadiyah Gamping No. 0914/PI.24.2/IV/2019 tanggal 23 April 2019.

\section{Hasil dan Pembahasan}

3.1. Hasil

3.1.1. Kualitas Pelayanan Rawat Inap dan Kepuasan Pasien Rawat Inap

Tabel 1. menunjukkan bahwa persepsi pasien tentang kualitas pelayanan rawat inap untuk masing-masing dimensi adalah baik (58\%), tetapi masih ada $42 \%$ mempunyai persepsi kualitas layanan yang tidak baik. Diantara lima dimensi yang paling rendah frekuensinya adalah empati, sedangkan yang paling tinggi adalah keandalan. Kepuasan pasien untuk masing-masing dimensi adalah puas (63\%), tetapi terdapat pasien yang tidak puas $37 \%$. Dimensi kepuasan yang paling rendah adalah bentuk fisik dan empati, sedangkan paling tinggi adalah jaminan. 
Tabel 1. Persepsi Pasien tentang Kualitas Pelayanan Rawat Inap dan Kepuasan Pasien

\begin{tabular}{lcccc}
\hline \multicolumn{1}{c}{ Dimensi } & \multicolumn{2}{c}{ Kualitas Pelayanan } & \multicolumn{2}{c}{ Kepuasan } \\
& Baik & Tidak Baik & Puas & Tidak Puas \\
\hline Bentuk Fisik & $110(64 \%)$ & $62(36 \%)$ & $112(65 \%)$ & $60(35 \%)$ \\
Keandalan & $111(65 \%)$ & $61(35 \%)$ & $127(74 \%)$ & $45(26 \%)$ \\
Daya tanggap & $109(63 \%)$ & $63(37 \%)$ & $122(71 \%)$ & $50(29 \%)$ \\
Jaminan & $101(59 \%)$ & $71(41 \%)$ & $128(74 \%)$ & $44(26 \%)$ \\
Empati & $91(53 \%)$ & $81(47 \%)$ & $112(65 \%)$ & $60(35 \%)$ \\
Lima dimensi & $100(58 \%)$ & $72(42 \%)$ & $109(63 \%)$ & $63(37 \%)$ \\
\hline
\end{tabular}

3.1.2 Hubungan Karakteristik Responden dengan Persepsi Pasien tentang Kualitas Pelayanan Rawat Inap

Persepsi pasien tentang kualitas layanan rawat inap yang baik sebagian besar adalah jenis kelamin perempuan, menikah, pendidikan SMA, tidak pernah dirawat di RS PKU Muhammadiyah Gamping dan mempunyai jaminan kesehatan (BPJS Kesehatan). Persepsi pasien tentang kualitas layanan rawat inap yang tidak baik adalah jenis kelamin perempuan, menikah, pendidikan SMA dan sarjana, tidak pernah dirawat di RS PKU Muhammadiyah Gamping dan mempunyai jaminan kesehatan (BPJS Kesehatan). Karakteristik responden yang berhubungan dengan persepsi pasien tentang kualitas pelayanan rawat inap adalah pendidikan $(p$-value $<0,05)$. Lebih rinci dapat dilihat pada Tabel 2.

Tabel 2. Hubungan Karakteristik Responden dengan Persepsi Pasien tentang Kualitas Pelayanan Rawat Inap

\begin{tabular}{|c|c|c|c|c|c|}
\hline \multirow{3}{*}{ Karakteristik Responden } & \multicolumn{4}{|c|}{ Kualitas Layanan } & \multirow{3}{*}{$\begin{array}{c}P . \\
\text { value }\end{array}$} \\
\hline & \multicolumn{2}{|c|}{ Baik } & \multicolumn{2}{|c|}{ Tidak Baik } & \\
\hline & $\mathbf{n}$ & $\%$ & $\mathbf{n}$ & $\%$ & \\
\hline \multicolumn{6}{|l|}{ Jenis Kelamin } \\
\hline Laki-laki & 28 & 28 & 14 & 19 & \multirow[b]{2}{*}{0,198} \\
\hline Perempuan & 72 & 72 & 58 & 81 & \\
\hline \multicolumn{6}{|l|}{ Status Pernikahan } \\
\hline Menikah & 82 & 82 & 67 & 93 & \multirow{3}{*}{0,069} \\
\hline Belum Menikah & 14 & 14 & 5 & 7 & \\
\hline Cerai Hidup/Cerai Mati & 4 & 4 & 0 & 0 & \\
\hline \multicolumn{6}{|l|}{ Pendidikan } \\
\hline Tidak Sekolah & 2 & 2 & 1 & 1 & \multirow{4}{*}{0,025} \\
\hline Rendah (SD, SMP) & 26 & 26 & 9 & 13 & \\
\hline $\begin{array}{l}\text { Sedang } \\
\text { (SMA/SMK/Sederajat) }\end{array}$ & 46 & 46 & 26 & 36 & \\
\hline $\begin{array}{l}\text { Tinggi (Diploma, } \\
\text { Sarjana, Magister) }\end{array}$ & 26 & 26 & 36 & 50 & \\
\hline \multicolumn{6}{|l|}{ Riwayat dirawat Di RS } \\
\hline Pernah & 43 & 43 & 30 & 42 & \multirow[t]{2}{*}{0,861} \\
\hline Tidak Pernah & 57 & 57 & 42 & 58 & \\
\hline \multicolumn{6}{|l|}{ Jaminan Kesehatan } \\
\hline $\mathrm{Ya}$ & 89 & 89 & 62 & 86 & \multirow[t]{2}{*}{0,568} \\
\hline Tidak & 11 & 11 & 10 & 14 & \\
\hline
\end{tabular}

3.1.3. Hubungan Karakteristik Responden dengan Kepuasan Pasien Rawat Inap

Tabel 3. menunjukkan bahwa karakteristik pasien yang merasakan puas sebagian besar adalah jenis kelamin perempuan, menikah, pendidikan SMA, tidak pernah dirawat di RS PKU Muhammadiyah Gamping dan mempunyai jaminan kesehatan (BPJS Kesehatan). Pasien yang merasakan tidak puas sebagian besar adalah jenis kelamin perempuan, menikah, pendidikan SMA, tidak pernah dirawat di RS PKU Muhammadiyah Gamping dan mempunyai jaminan kesehatan (BPJS Kesehatan). Karakteristik yang berhubungan secara signifikan dengan kepuasan pasien adalah riwayat pernah dirawat di RS PKU Muhammadiyah Gamping ( $p$-value<0,05). 
Tabel 3. Hubungan Karakteristik Responden dengan Kepuasan Pasien Rawat Inap

\begin{tabular}{|c|c|c|c|c|c|}
\hline \multirow{3}{*}{ Karakteristik Responden } & \multicolumn{4}{|c|}{ Kualitas Layanan } & \multirow{3}{*}{$\begin{array}{c}P \text { - } \\
\text { value }\end{array}$} \\
\hline & \multicolumn{2}{|c|}{ Baik } & \multicolumn{2}{|c|}{ Tidak Baik } & \\
\hline & $\mathbf{n}$ & $\%$ & $n$ & $\%$ & \\
\hline \multicolumn{6}{|l|}{ Jenis Kelamin } \\
\hline Laki-laki & 22 & 20 & 20 & 32 & \multirow{2}{*}{0,089} \\
\hline Perempuan & 87 & 80 & 43 & 68 & \\
\hline \multicolumn{6}{|l|}{ Status Pernikahan } \\
\hline Menikah & 95 & 87 & 54 & 86 & \multirow{3}{*}{0,195} \\
\hline Belum Menikah & 10 & 9 & 9 & 14 & \\
\hline Cerai Hidup/Cerai Mati & 4 & 4 & 0 & 0 & \\
\hline \multicolumn{6}{|l|}{ Pendidikan } \\
\hline Tidak Sekolah & 2 & 2 & 1 & 2 & \multirow{4}{*}{0,797} \\
\hline Rendah (SD, SMP) & 24 & 22 & 11 & 17 & \\
\hline $\begin{array}{l}\text { Sedang } \\
\text { (SMA/SMK/Sederaiat) }\end{array}$ & 46 & 42 & 26 & 41 & \\
\hline $\begin{array}{l}\text { Tinggi (Diploma, } \\
\text { Sarjana, Magister) }\end{array}$ & 37 & 34 & 25 & 40 & \\
\hline Riwayat dirawat Di RS & 53 & 49 & 20 & 32 & \\
\hline Pernah & 56 & 51 & 43 & 68 & 0,031 \\
\hline Tidak Pernah & & & & & \\
\hline Jaminan Kesehatan & 97 & 89 & 54 & 86 & \\
\hline $\mathrm{Ya}$ & 12 & 11 & 9 & 14 & 0,527 \\
\hline Tidak & 22 & 20 & 20 & 32 & \\
\hline
\end{tabular}

3.1.4. Hubungan Persepsi Pasien tentang Kualitas Layanan Rawat Inap dengan Kepuasan Pasien Rawat Inap Kelas III Rumah Sakit

Tabel 4. menunjukkan bahwa kualitas layanan rawat inap berhubungan dengan kepuasan pasien, baik untuk masing-masing dimensi maupun total lima dimensi kualitas $(p$-value< 0,05$)$. Hal ini menunjukkan bahwa semakin baik persepsi pasien tentang kualitas layanan rawat inap rumah sakit maka semakin tinggi kepuasan pasien.

Tabel 4. Hubungan Persepsi Pasien tentang Kualitas Layanan Rawat Inap dengan Kepuasan Pasien Rawat Inap Kelas III Rumah Sakit

\begin{tabular}{|c|c|c|c|c|c|c|}
\hline \multirow{3}{*}{ Dimensi } & \multirow{3}{*}{$\begin{array}{l}\text { Kualitas } \\
\text { Layanan }\end{array}$} & \multicolumn{4}{|c|}{ Kepuasan } & \multirow{3}{*}{$\begin{array}{c}P- \\
\text { value }\end{array}$} \\
\hline & & \multirow{2}{*}{$\begin{array}{c}\text { Puas } \\
\mathbf{n}\end{array}$} & & \multicolumn{2}{|c|}{ Tidak Puas } & \\
\hline & & & $\%$ & $\mathbf{n}$ & $\%$ & \\
\hline \multirow[t]{2}{*}{ Bentuk Fisik } & Baik & 81 & 74 & 29 & 46 & \multirow[t]{2}{*}{0,000} \\
\hline & Tidak Baik & 28 & 26 & 34 & 54 & \\
\hline \multirow[t]{2}{*}{ Keandalan } & Baik & 80 & 73 & 31 & 49 & \multirow[t]{2}{*}{0,001} \\
\hline & Tidak Baik & 29 & 27 & 32 & 51 & \\
\hline \multirow[t]{2}{*}{ Daya tanggap } & Baik & 77 & 71 & 32 & 51 & \multirow[t]{2}{*}{0,009} \\
\hline & Tidak Baik & 32 & 29 & 31 & 49 & \\
\hline \multirow{2}{*}{$\begin{array}{l}\text { Jaminan } \\
\text { Kepastian }\end{array}$} & Baik & 76 & 70 & 25 & 40 & \multirow[t]{2}{*}{0,000} \\
\hline & Tidak Baik & 33 & 30 & 38 & 60 & \\
\hline \multirow[t]{2}{*}{ Empati } & Baik & 76 & 70 & 15 & 24 & \multirow[t]{2}{*}{0,000} \\
\hline & Tidak Baik & 33 & 30 & 48 & 76 & \\
\hline \multirow[t]{2}{*}{ Lima Dimensi } & Baik & 78 & 72 & 22 & 35 & \multirow[t]{2}{*}{0,000} \\
\hline & Tidak Baik & 31 & 28 & 41 & 65 & \\
\hline
\end{tabular}

\subsection{Pembahasan}

Hasil penelitian pada Tabel 1. menunjukkan bahwa persepsi pasien tentang kualitas pelayanan rawat inap untuk masing-masing dimensi adalah baik (58\%), tetapi masih ada $42 \%$ mempunyai persepsi kualitas layanan yang tidak baik. Kualitas layanan rumah sakit 
bergantung pada sistem yang kompleks, termasuk profesionalisme dan kesadaran individu, infrastruktur kelembagaan yaitu masalah organisasi, ketersediaan peralatan dan kolaborasi interprofesional.(25) Kualitas pelayanan medis dan administrasi mempengaruhi loyalitas pasien rawat inap,(26) sehingga Pihak Rumah Sakit harus terus meningkatkan kualitas layanan rawat inap.

Aspek yang mempengaruhi kualitas layanan rumah sakit adalah daya tanggap, jaminan, keamanan, bukti nyata, komunikasi kesehatan dan orientasi pasien.(16) Diantara lima dimensi yang paling rendah frekuensinya adalah empati. Empati melambangkan peduli dan memahami pasien. Perhatian menunjukkan layanan pelanggan individual dan perhatian kepada pasien dan fokus pada pemahaman kebutuhan pasien. Selain sikap peduli, sikap personel dalam pelayanan, juga penting. Cara yang baik di mana penyedia layanan (dokter, perawat, dan tenaga kesehatan lainnya) berinteraksi dengan pasien, juga komunikasi dengan pasien, tingkat interaksi, tingkat komunikasi dua arah. $(27,28)$

Dimensi kualitas yang paling tinggi adalah keandalan, yang ditentukan sebagai kemampuan untuk melakukan layanan yang dijanjikan secara andal dan akurat. Akurasi menyajikan informasi tentang layanan secara jelas dan ringkas bahwa layanan tersebut harus secara langsung berkaitan dengan kesehatan manusia. Keakuratan informasi juga mencakup keakuratan diagnosa penyakit, keakuratan biaya operasi, dll. Image dan keahlian juga membuat rumah sakit dapat diandalkan. Semakin banyak rumah sakit menciptakan visi yang baik untuk umum, semakin kredibel jadinya. Keahlian mencerminkan kemampuan penyedia layanan untuk mematuhi standar pelayanan yang tinggi. Spesialisasi dokter, perawat atau personel sangat penting bagi pasien untuk percaya pada pelayanan rumah sakit(28). Berdasarkan hasil penelitian ini, maka Pihak Rumah Sakit harus lebih fokus pada empati, profesionalisme dan keandalan untuk melakukan pelayanan yang memuaskan dan berkualitas.

Persepsi pasien tentang kualitas layanan rawat inap dipengaruhi oleh berbagai aspek, antara lain karakteristik responden. Karakteristik responden pada Tabel 2. sebagian besar jenis kelamin perempuan, menikah, pendidikan SMA, mempunyai riwayat pernah dirawat di RS PKU Muhammadiyah Gamping dan menggunakan jaminan kesehatan (BPJS Kesehatan). Persepsi pasien tentang kualitas layanan rawat inap baik sebagian besar adalah jenis kelamin perempuan, menikah, pendidikan SMA, tidak pernah dirawat di RS PKU Muhammadiyah Gamping dan mempunyai jaminan kesehatan (BPJS Kesehatan). Persepsi pasien tentang kualitas layanan rawat inap tidak baik adalah jenis kelamin perempuan, menikah, pendidikan SMA dan sarjana, tidak pernah dirawat di RS PKU Muhammadiyah Gamping dan mempunyai jaminan kesehatan (BPJS Kesehatan). Karakteristik responden yang berhubungan dengan persepsi pasien tentang kualitas pelayanan rawat inap adalah pendidikan. Selain karakteristik pendidikan, karakteristik usia juga mempengaruhi persepsi pasien tentang kualitas layanan rawat inap rumah sakit.(29) Karakteristik jenis kelamin, status pernikahan, riwayat pernah dirawat di RS PKU Muhammadiyah Gamping dan penggunaan jaminan kesehatan (BPJS Kesehatan) tidak berhubungan dengan persepsi pasien tentang kualitas layanan rawat inap.

Selain karakteristik responden, banyak aspek yang dapat mempengaruhi kualitas layanan rawat inap rumah sakit tetapi tidak diteliti, antara lain karakteristik organisasi (kepuasan kerja dan tingkat persetujuan)30, sumber daya manusia, proses, kebijakan, infrastruktur 31 dan status kepemilikan rumah sakit (swasta atau pemerintah). $(32,33)$ Hasil penelitian pada Tabel 4. menunjukkan bahwa kualitas layanan rawat inap berhubungan dengan kepuasan pasien, baik untuk masing-masing dimensi maupun total lima dimensi. Hasil penelitian ini sejalan dengan penelitian Turan and Bozaykut bahwa persepsi kualitas layanan di Turki secara signifikan mempengaruhi kepuasan pasien.(34) Keandalan, daya tanggap, empati, bentuk fisik, dan jaminan mempengaruhi kepuasan pasien.(17) Dimensi yang paling kuat berhubungan dengan kepuasan pasien berbeda-beda berdasarkan hasil penelitian. Hasil penelitian Khanchitpol and Johnson William di India menyatakan bahwa daya tanggap paling berpengaruh terhadap kepuasan pasien, diikuti oleh empati, bentuk fisik, jaminan; dan akhirnya keandalan35. Berbeda dengan hasil penelitian Turan and Bozaykut di Turki bahwa dimensi bentuk fisik memiliki pengaruh paling kuat terhadap kepuasan pasien.(34) 
Hasil penelitian pada Tabel 1. menunjukkan bahwa kepuasan pasien untuk masingmasing dimensi adalah puas $(63,4 \%)$. Kualitas layanan yang dapat memuaskan pasien tersebut diharapkan dapat setara dengan hasil penilaian kualitas layanan rumah sakit di berbagai negara, antara lain di USA,(4,5) Swedia,(6) China,(7,8) Thailand,(9) Bulgaria, Hungaria, Lithuania, Polandia, Rumania dan Ukraina,(36) Arab Saudi,(37) Taiwan,(38) Albania,(23) India,(39-41) dan Israel.(42) Kepuasan pasien pada penelitian ini berbeda dengan penelitian di Iran yang menyatakan bahwa kualitas pelayanan rumah sakit kurang memuaskan pasien untuk semua dimensi pelayanan adalah di Iran.(10,11) Walaupun sebagian besar pasien puas, tetapi terdapat pasien yang tidak puas $37 \%$. Ketidakpuasan pasien tersebut sejalan dengan hasil penelitian Shan et al. bahwa pasien kurang puas terhadap layanan rawat inap RS di Heilongjiang China.(43) Dimensi kepuasan yang paling rendah dalam penelitian ini adalah bentuk fisik dan empati. Hasil penelitian ini sejalan dengan penelitian Derebe et.al. bahwa pasien tidak puas terhadap pelayanan RS di Amhara Barat Ethiopia karena kebersihan fasilitas yang buruk, ketersediaan layanan akses yang lebih sedikit, obat yang diresepkan kurang, dan jumlah waktu tunggu yang lama.(44) Demikian juga hasil evaluasi kualitas layanan RS di Jerman yaitu bentuk fisik menjadi prioritas tertinggi.(45) Dimensi bentuk fisik juga menunjukkan ketidakpuasan utama pada pasien di unit bedah rumah sakit perawatan tersier India yaitu kebersihan toilet, kualitas makanan, penjelasan tentang peraturan dan peraturan, perilaku petugas kebersihan dan kesiapan ruang.(39) Pasien rumah sakit di India juga menyatakan ketidakpuasan untuk kebersihan yang buruk dan fasilitas toilet yang tidak mencukupi.(41)

Dimensi kepuasan yang paling tinggi berdasarkan Tabel 1. adalah jaminan. Jaminan merupakan pengetahuan, kemampuan dan sopan santun tenaga kesehatan yang menginspirasi kepercayaan pasien. Dari aspek kepercayaan, jaminan juga mencakup informasi yang dimiliki pasien dirahasiakan rumah sakit dan jaminan keamanan / privasi pasien.(27) Perlindungan terhadap setiap jenis data pelanggan seperti informasi pasien, dan lain-lain sangat penting untuk kepercayaan pasien. Biaya pelayanan yang menguntungkan bagi pasien juga merupakan jaminan.(28) Sebagian besar responden dalam penelitian ini adalah pengguna jaminan kesehatan (BPJS Kesehatan), sehingga mempunyai kepuasan yang tinggi pada dimensi jaminan. Penelitian lain menunjukkan hasil berbeda dari penelitian ini, dimana berdasarkan hasil penelitian terdahulu daya tanggap paling berpengaruh terhadap kepuasan pasien di India, diikuti oleh empati, bentuk fisik, jaminan; dan akhirnya keandalan.(35) Adapun hasil penelitian Turan dan Bozaykut yang menyatakan bahwa dimensi bentuk fisik memiliki pengaruh paling kuat terhadap kepuasan pasien di Turki.(34)

Banyak aspek yang mempengaruhi kepuasan pasien terhadap layanan rawat inap, salah satunya karakteristik pasien. Tabel 3. menunjukkan bahwa karakteristik yang berhubungan secara signifikan dengan kepuasan pasien adalah riwayat pernah dirawat di RS PKU Muhammadiyah Gamping. Hasil penelitian tersebut sejalan dengan penelitian Lin bahwa pengalaman pasien mempengaruhi kepuasan pasien.(46) Sedangkan karakteristik jenis kelamin, status pernikahan, pendidikan, dan penggunaan jaminan kesehatan (BPJS Kesehatan) tidak berhubungan dengan kepuasan pasien. Hasil penelitian ini berbeda dengan penelitian Lin bahwa pendidikan pasien mempengaruhi kepuasan pasien.(46) Selain pendidikan, karakteristik usia juga mempengaruhi kepuasan pasien.(47)

Selain karakteristik pasien, banyak aspek yang mempengaruhi kepuasan pasien, antara lain komunikasi tenaga kesehatan (dokter dan perawat) yang baik, $(48,49)$ keramahan staf, jumlah informasi yang diberikan mengenai kondisi dan perawatan, ketersediaan saluran untuk mengajukan keluhan dan perasaan diperlakukan dengan hormat.(50) Aspek tersebut merupakan bagian dari dimensi jaminan dalam penelitian ini, yang merupakan dimensi kepuasan yang paling tinggi.

\section{Kesimpulan}

Persepsi pasien tentang kualitas layanan rawat inap di Rumah Sakit PKU Muhammadiyah Gamping sebagian besar adalah baik pada semua dimensi. Sebagian besar pasien menyatakan puas. Dimensi kualitas layanan yang perlu ditingkatkan adalah empati, sedangkan yang paling baik adalah keandalan. Karakteristik pendidikan berhubungan secara signifikan dengan persepsi pasien tentang kualitas layanan rawat inap rumah sakit. 
Persepsi pasien tentang kualitas layanan rawat inap rumah sakit berhubungan secara signifikan dengan kepuasan pasien. Pengalaman pasien dirawat di RS berhubungan secara signifikan dengan kepuasan pasien rawat inap. Dimensi kepuasan pasien yang perlu ditingkatkan adalah bentuk fisik dan empati.

\section{Daftar Pustaka}

1. Lupo T. A fuzzy framework to evaluate service quality in the healthcare industry: An empirical case of public hospital service evaluation in Sicily. Appl Soft Comput J 2016; 40: 468-478.

2. Amin $M$, Zahora Nasharuddin S. Hospital service quality and its effects on patient satisfaction and behavioural intention. An Int J Benchmarking An Int J Iss Int J Heal Care Qual Assur 2013; 18: 238-254.

3. Mohamed B, Azizan NA. Perceived service quality's effect on patient satisfaction and behavioural compliance. Int J Health Care Qual Assur 2015; 28: 300-314.

4. Baernholdt M, Keim-Malpass J, Hinton ID, et al. A Comparison of Quality of Care in Critical Access Hospitals and Other Rural Hospitals. Online J Rural Nurs Heal Care; 14. DOI: 10.14574/ojrnhc.v14i2.328.

5. Tehrani AB, Feldman SR, Camacho FT, et al. Patient Satisfaction with Outpatient Medical Care in the United States. Health Outcomes Res Med 2011; 2: e197-e202.

6. Johansson A, Ekwall A, Wihlborg J. Patient satisfaction with ambulance care services: Survey from two districts in southern Sweden. Int Emerg Nurs 2011; 19: 86-89.

7. Min Li1,\#, Douglas Bruce Lowrie1,\#, Cheng-Yu Huang2, Xiang-Chan Lu3, Ying-Chu Zhu4, Xing-Hua Wu5, Mayila Shayiti6, Qiong-Zhen Tan7, Hua-Ling Yang8, Si-Yuan Chen2, Pan Zhao2, Sheng-Hua He4, Xiu-Rong Wang9 H-ZL. Evaluating-patients-perception-of-service-quality-_2015_Asian-Pacific-Journ. Asian Pac J Trop Biomed 2015; 5 (6): 497-504.

8. $\mathrm{Xu} \mathrm{P}, \mathrm{Li} \mathrm{M}, \mathrm{Rst} \mathrm{F}$, et al. Application of case classifi cation in healthcare quality assessment in China. Heal Inf Manag J 2012; 41: 1833-3583.

9. Untachai S. Modeling Service Quality in Hospital as a Second Order Factor, Thailand. Procedia - Soc Behav Sci 2013; 88: 118-133.

10. Mohebifar R, Hasani H, Barikani A, et al. Evaluating Service Quality from Patients' Perceptions: Application of Importance-performance Analysis Method. Osong Public Heal Res Perspect 2016; 7: 233-238.

11. Asefzadeh S, Gholami S, Rajaee R, et al. Evaluation of the Quality of Health Service Providers: The Iranian People Perspective 2014. Electron physician 2016; 8: 201732080.

12. Sidik NA, Lazuardi L, Agung FH, et al. Assessment of the quality of hospital care for children in Indonesia. Trop Med Int Heal 2013; 18: 407-415.

13. Republik Indonesia. Undang-Undang Republik Indonesia Nomor 44 Tahun 2009 tentang Rumah Sakit. Indonesia, 2009.

14. Republik Indonesia. Peraturan Menteri Kesehatan Republik Indonesia Nomor 34 Tahun 2017 tentang Akreditasi Rumah Sakit. Indonesia, 2017.

15. Nila Farid Moeloek. Kebijakan Pembangunan Kesehatan. Jakartahttp://www.depkes.go.id/ (2016).

16. Shafii M, Rafiei S, Abooee F, et al. Assessment of Service Quality in Teaching Hospitals of Yazd University of Medical Sciences: Using Multi-criteria Decision Making Techniques. Osong Public Heal Res Perspect 2016; 7: 239-247.

17. Aliman NK, Mohamad WN. Linking Service Quality, Patients' Satisfaction and Behavioral Intentions: An Investigation on Private Healthcare in Malaysia. Procedia - Soc Behav Sci 2016; 224: 141-148.

18. Meesala A, Paul J. Service quality, consumer satisfaction and loyalty in hospitals: Thinking for the future. J Retail Consum Serv 2016; 1-9.

19. Suryati, Syaifudin. Hubungan antara Mutu Pelayanan Keperawatan dengan Kepuasan Pasien Rawat Inap Di Kelas III RS. PKU Muhammadiyah Yogyakarta. Sekolah Tinggi IImu Kesehatan 'Aisyiyah Yogyakarta, 2012.

20. Wijiwinarsih A. Hubungan Mutu Pelayanan Kebidanan pada lbu Nifas dengan Tingkat Kepuasan Pasien Di RS PKU Muhammadiyah Unit II Yogyakarta. Universitas 'Aisyiyah 
Yogyakarta, 2016.

21. Myers JL, Well AD. Research Design and Statistical Analysis. 2nd ed. Mahwah, New Jersey: Lawrence Erlbaum Associates, Inc., 2002.

22. Singer T (ed). Statistical Methods. Second. Burlington, Massachusetts, USA: Academic Press An imprint of Elsevier Science, 2003.

23. Kalaja R, Myshketa R, Scalera F. Service Quality Assessment in Health Care Sector: The Case of Durres Public Hospital. Procedia - Soc Behav Sci 2016; 235: 557-565.

24. Utami L, Hapsari S, Widyandana. Hubungan Antara Sikap dan Perilaku Kolaborasi dan Praktik Kolaborasi Interprofesional Di Ruang Rawat Inap Rumah Sakit Panti Rapih. J Keperawatan Muhammadiyah 2016; 1: 7-15.

25. Elizabeth McCay, Kristin Cleverley, Audrey Danaher NM. Collaborative partnershipsbridging the knowledge practice gap in client-centred care in mental health. $J$ Ment Heal Training, Educ Pract 2015; 10: 51-60.

26. Sinabutar R. Influence of the Quality of Medical and Administrative Services on the Inpatients' Loyalty at the Adventist Hospital Bandung. Int J Heal Med Sci 2017; 3: 13-22.

27. Parasuraman A, ZeithamI VA, Berry LL. A Conceptual Model of Service Quality and Its Implications for Future Research. Source J Mark 1985; 49: 41-50.

28. Büyüközkan $\mathrm{G}$, Çiff̧i $\mathrm{G}$, Güleryüz $\mathrm{S}$. Strategic analysis of healthcare service quality using fuzzy AHP methodology. Expert Syst Appl 2011; 38: 9407-9424.

29. Andrade C, Lima ML, Fornara F, et al. Users' views of hospital environmental quality: Validation of the Perceived Hospital Environment Quality Indicators (PHEQIs). J Environ Psychol. Epub ahead of print 2012. DOI: 10.1016/j.jenvp.2011.12.001.

30. Kim J, Han W. Improving Service Quality in Long-term Care Hospitals: National Evaluation on Long-term Care Hospitals and Employees Perception of Quality Dimensions. Osong Public Heal Res Perspect 2012; 3: 94-99.

31. Handayani PW, Hidayanto AN, Sandhyaduhita PI, et al. Strategic hospital services quality analysis in Indonesia. Expert Syst App/ 2015; 42: 3067-3078.

32. Ahmed S, Abd Manaf NH, Islam R. Measuring quality performance between public and private hospitals in Malaysia. Int J Qual Serv Sci. Epub ahead of print 2017. DOI: 10.1108/IJQSS-02-2017-0015.

33. Ahmed S, Md K, Tarique. Service quality, patient satisfaction and loyalty in the Bangladesh healthcare sector. Int J Health Care Qual Assur 2017; 30: 477-488.

34. Turan A, Bozaykut T. Analyzing perceived healthcare service quality on patient related outcomes. Int J Qual Serv Sci 2016; 8: 478-497.

35. Khanchitpol Y, Johnson William C. Leadership in Health Services Measuring hospital out-patient service quality in Thailand. Leadersh Heal Serv An Int J Int J Heal Care Qual Assur 2013; 26: 338-355.

36. Stepurko T, Pavlova M, Groot W. Overall satisfaction of health care users with the quality of and access to health care services: a cross-sectional study in six Central and Eastern European countries. BMC Health Serv Res. Epub ahead of print 2016. DOI: 10.1186/s12913-016-1585-1.

37. Alshehri A, Alomar Y, Mohammed G, et al. A survey on postanesthetic patient satisfaction in a university hospital. Saudi $J$ Anaesth. Epub ahead of print 2015. DOI: 10.4103/1658-354X.158499.

38. Chen $\mathrm{CH}$, Liau YJ, Wu PF. Inpatient satisfaction with TCM medication counseling services provided by pharmacists. Eur J Integr Med. Epub ahead of print 2012. DOI: 10.1016/j.eujim.2012.02.002.

39. Mishra PH, Gupta S. Study of patient satisfaction in a surgical unit of a tertiary care teaching hospital. J Clin Orthop Trauma. Epub ahead of print 2012. DOI: 10.1016/j.jcot.2012.04.002.

40. Devadasan N, Criel B, Damme W Van, et al. Community health insurance schemes \& patient satisfaction - evidence from India i. Indian J Med Res 2011; 133: 40-49.

41. Sudhan A, Khandekar R, Deveragonda S, et al. Patient satisfaction regarding eye care services at tertiary hospital of central India. Oman J Ophthalmol; 4. Epub ahead of print 2011. DOI: $10.4103 / 0974-620 X .83657$.

42. Shuv-Ami A, Shalom T. International Journal of Organizational Analysis Demographic differences of perceived service quality in emergency rooms of hospital 
organizations"Factor selection for service quality evaluation: a hospital case study". Int $\mathrm{J}$ Organ Anal TQM J Iss Int J Heal Care Qual Assur 2017; 25: 282-294.

43. Shan L, Li Y, Ding D, et al. Patient satisfaction with hospital inpatient care: Effects of trust, medical insurance and perceived quality of care. PLoS One. Epub ahead of print 2016. DOI: 10.1371/journal.pone.0164366.

44. Derebe MM, Shiferaw MB, Ayalew MA. Low satisfaction of clients for the health service provision in West Amhara region, Ethiopia. PLoS One. Epub ahead of print 2017. DOI: 10.1371/journal.pone.0179909.

45. Izadi A, Jahani Y, Rafiei S, et al. International Journal of Health Care Quality Assurance"Factor selection for service quality evaluation: a hospital case study". Int J Heal Care Qual Assur Int J Heal Care Qual Assur Iss Int J Heal Care Qual Assur 2017; 30: 656-663.

46. Lin HC. A study on women\&\#x2019;s perceptions regarding the requirements and satisfaction of a hospital environment. Genomic Med Biomarkers, Heal Sci 2011; 3: 6371.

47. Mitropoulos $\mathrm{P}$, Vasileiou $\mathrm{K}$, Mitropoulos I. Understanding quality and satisfaction in public hospital services: A nationwide inpatient survey in Greece. J Retail Consum Serv 2017; 0-1.

48. Puri N, Gupta A, Aggarwal AK, et al. Outpatient satisfaction and quality of health care in North Indian medical institute. Int J Health Care Qual Assur. Epub ahead of print 2012. DOI: $10.1108 / 09526861211270631$.

49. Lee S, Kim EK. The Effects of Korean Medical Service Quality and Satisfaction on Revisit Intention of the United Arab Emirates Government Sponsored Patients. Asian Nurs Res (Korean Soc Nurs Sci) 2017; 11: 142-149.

50. Sika Avortri Andy Beke Gordon Abekah-Nkrumah G, Hollins Martin C, Fleming V, et al. International Journal of Health Care Quality Assurance Predictors of satisfaction with child birth services in public hospitals in Ghana Predictors of satisfaction with child birth services in public hospitals in Ghana. Int J Heal Care Qual Assur Int J Heal Care Qual Assur Int J Heal Care Qual Assur Iss Int J Public Sect Manag 2011; 24: 223-237. 